TAPROBANICA, ISSN 1800-427X. June, 2014. Vol. 06, No. 01: pp. 66-67.

(C) Research Center for Climate Change, University of Indonesia, Depok, Indonesia \& Taprobanica Private Limited, Homagama, Sri Lanka http://www.sljol.info/index.php/tapro

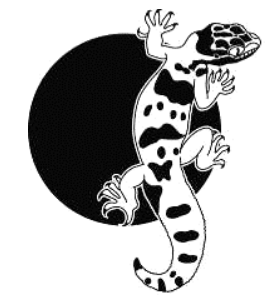

\section{On the nectar feeding by the fulvous fruit bat (Rousettus leschenaulti)}

Phytophagous or fruit bats feed primarily on fruits, seeds, and flower buds. Some fruit bats also feed on flower nectar, a habit that affects pollination and plant dispersal. As a consequence of chiropteran nectarivory many commercially important plant species are known to be pollinated (Krishnan, 2001). Nectar is an important source of carbohydrates and water for bats (Ruby et al., 2000). Plant characteristics that influence pollination include time of anthesis; mode of nectar secretion; the colour, odour, morphology, position of flowers; the amount and protein content of pollen; the volume of nectar; and, the concentration of sugar (Faegri \& van der Pijl, 1979).

Thirty species of bat have been recorded in Sri Lanka of which four, Rousettus leschenaulti, Pteropus giganteus, Cynopterus sphinx, and $C$. brachyotis, all belonging to the sub-Order Yinpterochiroptera and Family Pteropodidae, are almost exclusively frugivorous and nectarivorous although a few insects or even vertebrates may be ingested by foraging animals (Yapa \& Ratnavira, 2013). Rousettus leschenaulti or the fulvous fruit bat has an altitudinal range extending from sea level to 1500m (Phillips, 1980). Its diurnal roosts are located in caves, deserted buildings, disused tunnels and occasionally, trees. $R$. leschenaulti is exceptional in that it is the only known fruit bat in the world with echolocation ability albeit a very simple system. The ultrasound becomes useful in finding their way within their dark cave or tunnel roosts (Yapa \& Ratnavira, 2013). Generally, It lives in colonies which may number from as little as 2-3 individuals up to several thousand (Bates \& Harrison, 1997).

The diet of $R$. leschenaulti in Sri Lanka consists of fruit juices, pulp, flower nectar, and leaves (Phillips, 1980). A fine sense of smell guides these bats to fruit- and flower-bearing trees kilometers away and, while foraging; $R$. leschenaulti may share the patchily distributed bountiful tree with other fruit bat species. There is some evidence that resource partitioning may occur via the heights at which the different species exploit fruits and flowers in a given tree (Yapa \& Ratnavira, 2013). In the course of obtaining nectar from different flowers, these bats will be in contact with pollen. These results in the rubbing of pollen on the faces of bats and, during the course of a night's foraging, an individual bat will visit several flowers in perhaps several trees of the same species transferring pollen from the anther to the stigma, the basis of chiropterophily. Fulvous fruit bats feed upon many kinds of flowers and fruits notably guava (Psydium guajava), soursop (Annona sp.), silk cotton (Bombax sp.) and banana (Musa x paradisiaca) (Phillips, 1980). Many species of fruit tree depend on bats to pollinate flowers and the colour, size, odour, and shape of these flowers encourage bats to visit. For example, the bracts covering the inflorescences of banana begin to open about 30 minutes after sunset and a number of creamy white flowers emerge that last just one night. Maximum exploitation of banana flowers was around 20:00 h which was the time of maximum nectar production and sugar concentration in the flowers (Elangovan et al., 2000).

Our observations were made on 10 December, 2009 commencing at 20:14 $\mathrm{h}$ in a suburban garden at Kesbewa, Colombo District, Sri Lanka where there was a small clump of banana plants. The observation site was at an elevation of $38 \mathrm{~m}$ a.s.1. located in the Wet Zone of the country approximately $21 \mathrm{~km}$ from Colombo. The night was cloudy and the temperature $25^{\circ} \mathrm{C}$.

We observed a fulvous fruit bat flying around a small cluster of banana plants at the observation site. The banana plant had a height of about $3 \mathrm{~m}$ 
and carried an unopened inflorescence. This inflorescence was $30 \mathrm{~cm}$ in length and $28 \mathrm{~cm}$ in width. The single bat made several circling flights around the banana plant and then approached the inflorescence before turning back. It then returned within seconds and flew close to the inflorescence a few times at heights between $2-2.8 \mathrm{~m}$ from ground level. Soon after, the bat landed on the cone of inflorescence although the bract had not yet opened. The bat then briefly looked around while wiggling its ears presumably to determine if the coast was clear, then started to open the bract of the banana inflorescence using its muzzle. Opening the bract took $35 \mathrm{sec}$. After opening the bract the bat immediately crawled toward the flowers, put its rostrum into them, and lapped nectar for nearly 25 seconds (Fig. 1). Then it looked around again for 12 seconds, all the while wiggling its ears, presumably to check for safety. After that the bat continued to lap nectar for another 20sec. Finally, it flew away.

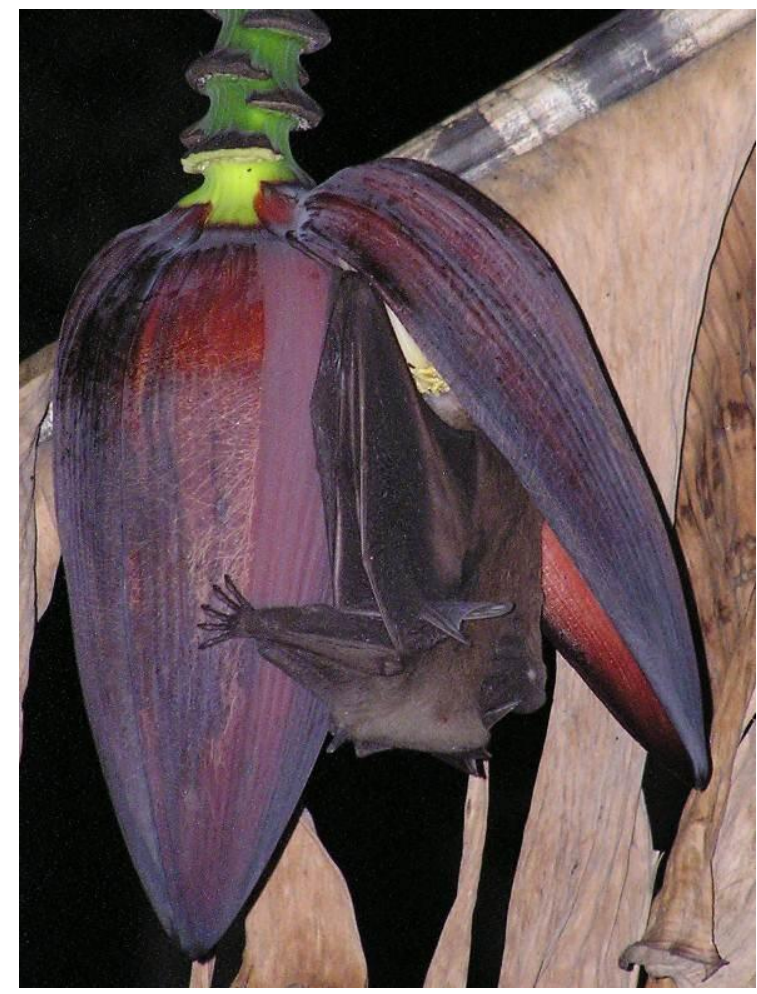

Figure 1: Nectar lapping behavior after the opening of Banana bract.

There is no published record we know of forced bract opening of banana inflorescences by fulvous fruit bats. Elangovan et al. (2000) stated that the animals wait until the bracts open naturally in order to commence feeding. We speculate that $R$. leschenaulti starts 'force' feeding prior to bract opening in order to counter resource competition.

\section{Literature cited}

Bates, P. J. J. and D. L. Harrison, 1997. Bats of the Indian Subcontinent. Harrison Zoological Museum publication, Kent, UK: 258.

Elangovan, V., G. Marimuthu, and T. H. Kunz, 2000. Nectar feeding behavior in the short-nosed fruit bat Cynopterus sphinx (Pteropodidae). Acta Chiropterologica, 2: 1-5.

Faegri, K. and L. van der Pijl, 1979. The principles of pollination ecology. $3^{\text {rd }}$ edition. Pergamon Press, Oxford: 244.

Krishnan, R., 2001. Observations on food and roosting habits of Indian short-nosed fruit bat Cynopterus sphinx (Vahl) (Chiroptera: Pteropodidae) at the I.I.Sc. Campus, Bangalore. Zoos' print journal, 16: 592-593.

Phillips, W. W. A., 1980. Manual of the Mammals of Sri Lanka - part II $\left(2^{\text {nd }}\right.$ revised edition). Wildlife and Nature Protection Society of Sri Lanka: 267.

Ruby, J., P. T. Nathan, J. Balasingh and T. H. Kunz, 2000. Chemical composition of fruits and leaves eaten by the Short-nosed fruit bat, Cynopterus sphinx (Chiroptera: Pteropodidae). Journal of Chemical Ecology, 26: 2825-2841.

Yapa, A. and G. Ratnavira, 2013. The Mammals of Sri Lanka. Department of Zoology, University of Colombo, Sri Lanka: 364-365.

Submitted: 30 Sept. 2013, Accepted: 23 April 2014 Section Editor: Asoka Yapa

W. G. M. Edirisinghe ${ }^{1} \&$ T. G. T. Kusuminda ${ }^{2}$

${ }^{1}$ Wild Rescue Team of Sri Lanka, 183/6 Horana Road, Kesbewa, Piliyandala, Sri Lanka Email: gayan.yza@gmail.com

${ }^{2}$ Department of Export Agriculture, Faculty of Agricultural Sciences, Sabaragamuwa University of Sri Lanka, Belihul-oya, Sri Lanka Email: t.kusuminda@gmail.com 